Chapman University

Chapman University Digital Commons

Pharmacy Faculty Articles and Research

School of Pharmacy

$11-29-2018$

\title{
Comparative Molecular Transporter Efficiency of Cyclic Peptides Containing Tryptophan and Arginine Residues
}

\author{
Samara E. Hanna \\ Chapman University \\ Saghar Mozaffari \\ Chapman University, mozaf100@mail.chapman.edu
}

Rakesh Tiwari

Chapman University, tiwari@chapman.edu

Keykavous Parang

Chapman University, parang@chapman.edu

Follow this and additional works at: https://digitalcommons.chapman.edu/pharmacy_articles

\section{Recommended Citation}

Hanna, S. E.; Mozaffari, S.; Tiwari, R. K.; Parang, K. Comparative molecular transporter efficiency of cyclic peptides containing tryptophan and arginine residues. ACS Omega 2018, 3, 16281-16291. doi: 10.1021/acsomega.8b02589

This Article is brought to you for free and open access by the School of Pharmacy at Chapman University Digital Commons. It has been accepted for inclusion in Pharmacy Faculty Articles and Research by an authorized administrator of Chapman University Digital Commons. For more information, please contact laughtin@chapman.edu. 


\section{Comparative Molecular Transporter Efficiency of Cyclic Peptides Containing Tryptophan and Arginine Residues}

\section{Comments}

This article was originally published in ACS Omega, volume 3, in 2018. DOI: 10.1021/acsomega.8b02589

This is an open access article published under an ACS AuthorChoice License, which permits copying and redistribution of the article or any adaptations for non-commercial purposes.

\section{Copyright}

American Chemical Society 


\title{
Comparative Molecular Transporter Efficiency of Cyclic Peptides Containing Tryptophan and Arginine Residues
}

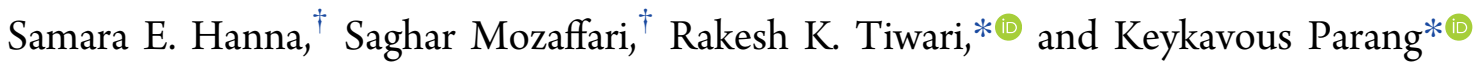 \\ Center for Targeted Drug Delivery, Department of Biomedical and Pharmaceutical Sciences, Chapman University School of \\ Pharmacy, Harry and Diane Rinker Health Science Campus, Irvine, California 92618, United States
}

\section{Supporting Information}

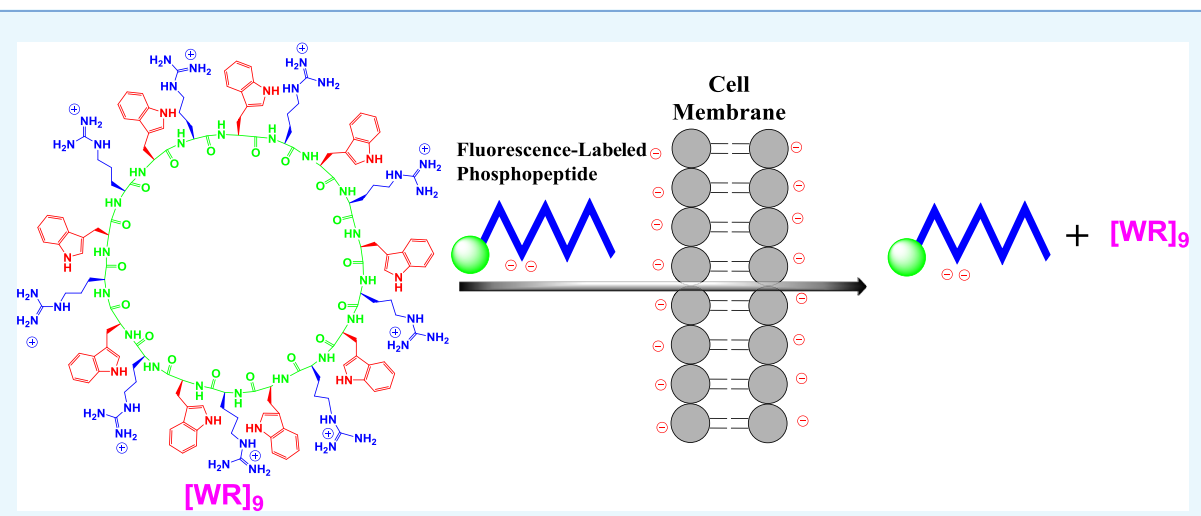

ABSTRACT: Cyclic peptides containing tryptophan $(\mathrm{W})$ and arginine $(\mathrm{R})$ residues, $[\mathrm{WR}]_{5},[\mathrm{WR}]_{6},[\mathrm{WR}]_{7},[\mathrm{WR}]_{8}$, and $[\mathrm{WR}]_{9}$, were synthesized through Fmoc solid-phase chemistry to compare their molecular transporter efficiency. The in vitro cytotoxicity of the peptides was evaluated using human leukemia carcinoma cell line (CCRF-CEM) and normal kidney cell line (LLC-PK1). [WR $]_{6},[\mathrm{WR}]_{7},[\mathrm{WR}]_{8}$, and $[\mathrm{WR}]_{9}$ were not significantly cytotoxic to LLC-PK1cells at a concentration of $10 \mu \mathrm{M}$ after $3 \mathrm{~h}$ incubation. Among all the peptides, $[\mathrm{WR}]_{9}$ was found to be a more efficient transporter than $[\mathrm{WR}]_{5},[\mathrm{WR}]_{6},[\mathrm{WR}]_{7}$, and $[\mathrm{WR}]_{8}$ in CCRF-CEM cells for delivery of a cell-impermeable fluorescence-labeled negatively charged phosphopeptide $\left(\mathrm{F}^{\prime}\right.$ GpYEEI). [WR $]_{9}(10 \mu \mathrm{M})$ improved the cellular uptake of $\mathrm{F}^{\prime}$-GpYEEI $(2 \mu \mathrm{M})$ by 20 -fold. The cellular uptake of a fluorescent conjugate of $[\mathrm{WR}]_{9}, \mathrm{~F}^{\prime}-\left[\mathrm{W}_{9} \mathrm{R}_{8} \mathrm{~K}\right]$, was increased in a concentration- and time-dependent pattern in CCRF-CEM cells. The uptake of $F^{\prime}-\left[W_{9} R_{8} K\right]$ was slightly reduced in CCRF-CEM cells in the presence of different endocytic inhibitors, such as nystatin, 5-( $N$-ethyl- $N$-isopropyl)amiloride, chlorpromazine, chloroquine, and methyl $\beta$-cyclodextrin. Furthermore, the uptake of $\mathrm{F}^{\prime}-\left[\mathrm{W}_{9} \mathrm{R}_{8} \mathrm{~K}\right]$ was shown to be temperature-dependent and slightly adenosine 5 '-triphosphate-dependent. The intracellular/ cellular localization (in the nucleus and cytoplasm) of $\mathrm{F}^{\prime}-\left[\mathrm{W}_{9} \mathrm{R}_{8} \mathrm{~K}\right]$ was confirmed by fluorescent microscopy in CCRF-CEM cells. These studies suggest that large cyclic peptides containing arginine and tryptophan can be used as a molecular transporter of specific compounds.

\section{INTRODUCTION}

The properties of the cell membrane create a barrier for the efficient cellular delivery of therapeutics. The cell membrane contains phospholipids, which are negatively charged and extremely hydrophobic. The phospholipids have been shown to obstruct the transportation of negatively charged or waterinsoluble molecules. For example, phosphopeptides are cellimpermeable compounds that are used as probes for studying phosphoprotein-protein interactions. ${ }^{1-3}$ Phosphopeptides consist of negatively charged phosphate groups that create an obstacle for them to enter the negatively charged phospholipids that make up the cell membrane of cells. Furthermore, a number of anticancer and anti-human immunodeficiency virus (HIV) agents have limited cellular uptake and/or a more efficient uptake is required for improving their biological properties. Thus, the development of cellular delivery systems for enhancing the delivery of cell-impermeable compounds, such as phosphopeptides, and/or improving the delivery of other biologically important compounds is urgently needed.

Cell-penetrating peptides (CPPs) have been introduced as a drug delivery system for various applications. ${ }^{4-6}$ CPPs have been shown to facilitate drug transport across the cell membrane and increase the cellular uptake of the drug. Other commonly used drug delivery systems include liposomes and micelles. Encapsulating the drug in a liposome has demonstrated to increase the efficiency of drug delivery and prevent damage to the normal tissue. However, a previous study has shown that liposomes still cause drug leakage, especially for highly hydrophilic drugs such as doxorubicin (Dox) that is one of the most widely administered drugs for

Received: September 29, 2018

Accepted: November 14, 2018

Published: November 29, 2018 


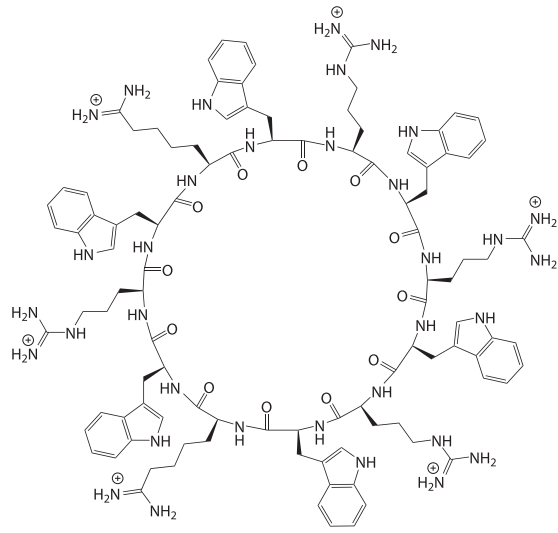

$[\text { WR }]_{6}$

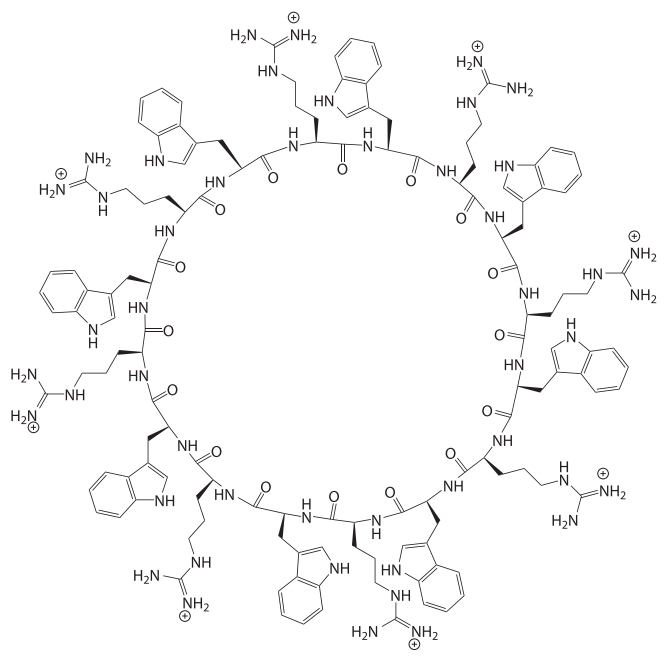

$[\mathrm{WR}]_{8}$

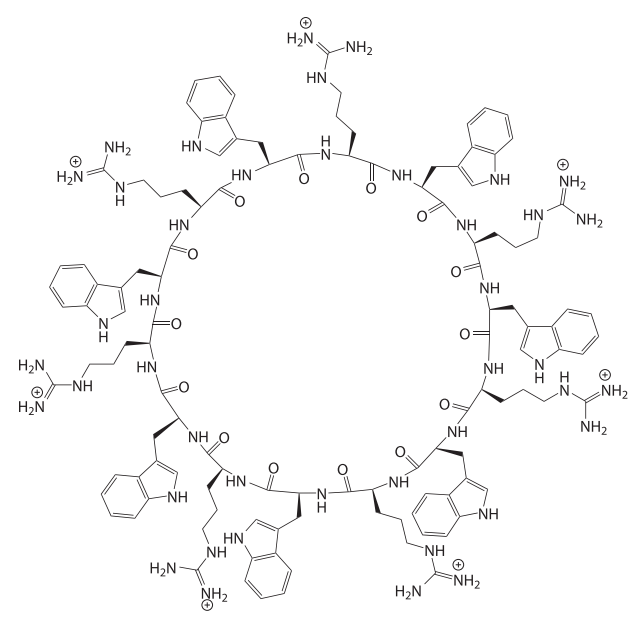

$[\mathrm{WR}]_{7}$

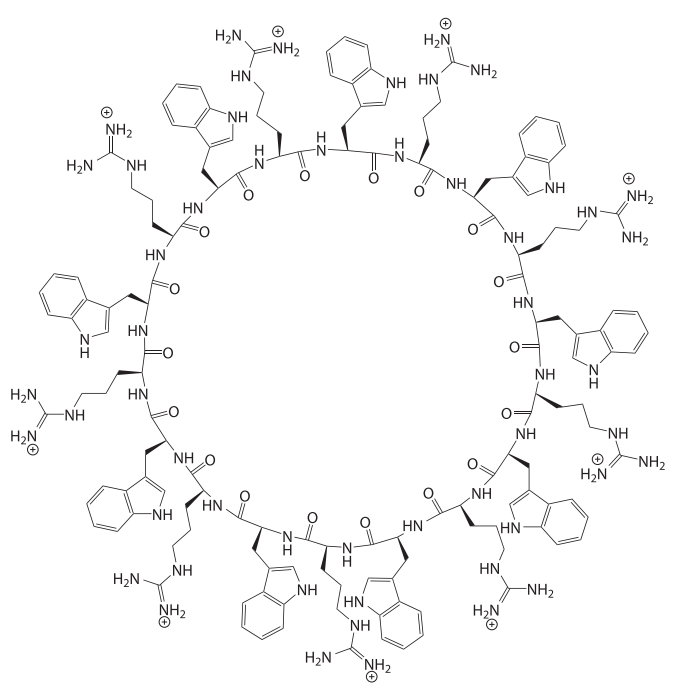

$[\mathrm{WR}]_{9}$

Figure 1. Chemical structures of synthesized cyclic peptides.

the treatment of cancer. ${ }^{8}$ Cancer cells can develop resistance to certain types of anticancer drugs, such as Dox. Furthermore, the high dose of the drug has been shown to cause irreversible damage to the cardiac muscle. ${ }^{9}$ Thus, the advancement of efficient and safe vehicles to enhance the targeted delivery of drugs to specific cells needs further studies.

There are many ways that the cellular uptake of CPPs may occur. The most common ways include direct penetration and endocytosis. Direct penetration may include inverted micelle formation and pore formation. The endocytotic pathway involves several pathways, such as macropinocytosis, phagocytosis, endocytosis-independent of clathrin, or endocytosisdependent on the coat proteins clathrin or caveolin. ${ }^{10,11}$ The CPPs that enter through an endosomal pathway may be degraded by enzymes or have an inadequate amount of drug released in the cytoplasm or nucleus. The best strategy to overcome this limitation is to create a compound that will bypass the endosomal pathway or enhance the rate of escape from the endosome. ${ }^{12}$

We have previously reported the application of cyclic peptide CPPs containing arginine (R) and tryptophan (W) residues for delivery of different cargo molecules. The data confirmed that cyclic peptides containing alternating trypto- phan and arginine residues, $[\mathrm{WR}]_{4}$ and $[\mathrm{WR}]_{5}$, improved the cellular uptake of compounds, such as anti-HIV drugs, Dox, phosphopeptides, and siRNA or generated peptide nanostructures. ${ }^{13-21}$ Studies also showed that the amino acid sequences in this peptide were oriented in such a way to allow the peptide to cross the cell membrane easily without causing cytotoxicity in the cell. ${ }^{9}$ Cyclic peptides were more rigid and expected to be more stable toward proteolytic degradation. The cyclic nature of the peptides provided higher stability versus the linear counterparts and more efficient cell penetration. We also showed that the cellular uptake of $[\mathrm{WR}]_{4}$ and $[\mathrm{WR}]_{5}$ is independent of the endocytotic pathway. ${ }^{13}$ We have also reported that $[\mathrm{WR}]_{5}$ and $[\mathrm{WR}]_{5}$-capped gold nanoparticles improved the cellular delivery of siRNA in HeLa cells by 2and 3.8 -fold, respectively. ${ }^{16}$

In continuation of our efforts to develop structure-cellular uptake relationship for cyclic peptides containing $\mathrm{W}$ and $\mathrm{R}$ residues, herein we synthesized and evaluated amphiphilic cyclic CPPs composed of increasing numbers of $\mathrm{W}$ and $\mathrm{R}$ residues, compared their efficiency with $[\mathrm{WR}]_{5}$ in improving the cellular uptake of cell-impermeable compounds, established structure-molecular transporter efficiency relationship, and evaluated the mechanism of cellular uptake. 
Scheme 1. Synthesis of $[\mathrm{WR}]_{9}$.
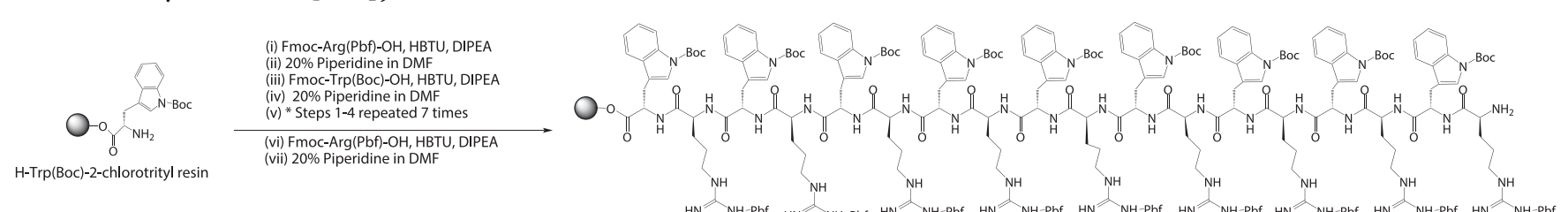

(i) Resin Cleavage: DCM:TFE:ACOH (7:2:1)

(iii) Final Cleavage: TFA, Anisole, Thioanisole, 1,2 ethanedithiol
(ii)

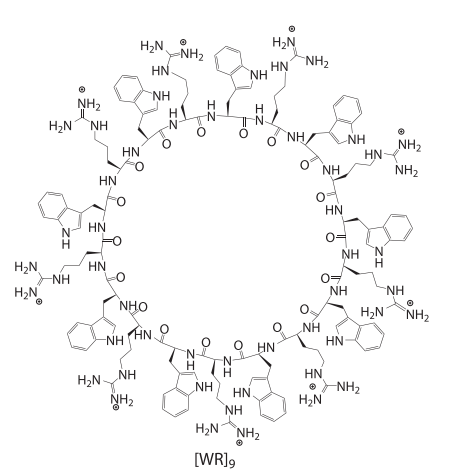

Thus, five cyclic peptides, $[\mathrm{WR}]_{5},[\mathrm{WR}]_{6},[\mathrm{WR}]_{7},[\mathrm{WR}]_{8}$, and $[\mathrm{WR}]_{9}$, were synthesized containing alternate tryptophan and arginine residues (Figure 1). The studies allowed us to determine if there was any effect on the molecular transporter efficiency of the cyclic peptide by increasing the number of hydrophobic and positively charged residues. Cytotoxicity of the cyclic peptides was determined to find an appropriate noncytotoxic concentration for cellular uptake studies. Using leukemia cancer (CCRF-CEM) cells, the cellular uptake studies were evaluated to measure the uptake of fluorescence-labeled compounds [e.g., phosphopeptide, stavudine (d4T), emtricitabine (FTC), lamivudine (3TC)] in the presence of the synthesized peptides $[\mathrm{WR}]_{5},[\mathrm{WR}]_{6},[\mathrm{WR}]_{7}$, $[\mathrm{WR}]_{8}$, and $[\mathrm{WR}]_{9}$ compared to parent analogs in the absence of the synthesized peptides. Structure-molecular transporter efficiency relationship of the compounds was determined. A fluorescence-labeled derivative of the most efficient peptide was evaluated in the presence and absence of different endocytosis inhibitors, and the uptake was evaluated using fluorescence microscopy.

\section{RESULTS AND DISCUSSION}

Chemistry. Fmoc-solid phase peptide synthesis and solution phase synthesis was used to synthesize all the peptides $[\mathrm{WR}]_{x}(x=5-9)$ (Figure 1). The linear side-chain protected peptides were assembled on $\mathrm{H}$-Trp(Boc)-2-chlorotrityl resin first. After the cleavage of the peptides from the resin in the presence of dichloromethane (DCM)/trifluoroethanol (TFE)/acetic acid $(\mathrm{AcOH})$, the $N$ - to $C$-terminal cyclization was conducted in the presence of $N, N^{\prime}$ diisopropylcarbodiimide (DIC), 1-hydroxy-7-azabenzotriazole (HOAt), and $N, N$-diisopropylethylamine (DIPEA). Final deprotection was carried out, and the peptides were purified using reverse-phase high-performance liquid chromatography (HPLC) and characterized by using high-resolution matrixassisted laser desorption/ionization time-of-flight (MALDITOF) mass spectrometry. As a representative example, the synthesis of $[\mathrm{WR}]_{9}$ is depicted in Scheme 1.

To synthesize the fluorescence-labeled cyclic peptide (Scheme 2), the peptide sequence was partially modified. The $N$-terminal arginine was replaced with Fmoc-Lys(Boc)$\mathrm{OH}$. Appropriately protected amino acids were assembled on
H-Trp(Boc)-2-chlorotrityl resin $(0.3 \mathrm{mmol} / \mathrm{g})$ according to the solid-phase synthesis strategy described above. After the cyclization and removal of all protecting groups, $\mathrm{N}$ hydroxysuccinimidyl ester (NHS) of 5(6)-carboxyfluorescein $\left(\mathrm{F}^{\prime}\right)$ was used for labeling the peptide. $\left[\mathrm{W}_{9} \mathrm{R}_{8}\right] \mathrm{K}$ peptide and 5(6)-carboxyfluorescein $N$-hydroxysuccinimide ester (FAMNHS) were coupled in the presence of DIPEA in anhydrous $\mathrm{N}, \mathrm{N}$-dimethylformamide (DMF). The coupling reaction was completed in overnight. The purification was conducted according to the described general method above used for other cyclic peptides to yield $\mathrm{F}^{\prime}-\left[\mathrm{W}_{9} \mathrm{R}_{8} \mathrm{~K}\right]$ (Scheme 2 ). The syntheses of fluorescence-labeled phosphopeptide $\mathrm{F}^{\prime}$ GpYEEI, $\mathrm{F}^{\prime}$-d4T, $\mathrm{F}^{\prime}$-3TC, and $\mathrm{F}^{\prime}$-FTC have been previously reported by us, ${ }^{15,22-24}$ where $F^{\prime}$ is 5(6)-carboxyfluorescein.

In Vitro Cytotoxicity Assay of Peptides. To evaluate the cytotoxicity of $[\mathrm{WR}]_{x}(x=5-9)$, cell viability assay was employed in normal kidney LLC-PK1 cell line at the experimental concentration of $25 \mu \mathrm{M}$ (Figure 2). Dox (5 $\mu \mathrm{M})$ was used as a positive control. The percentage of cell survival demonstrated that the peptides $[\mathrm{WR}]_{5}$ and $[\mathrm{WR}]_{6}$ did not show any significant toxicity at this concentration, whereas Dox was cytotoxic even at $5 \mu \mathrm{M}$. The cytotoxicity was gradually increased as the number of tryptophan and arginine increased in the cyclic peptides. For example, $[\mathrm{WR}]_{7}$ and $[\mathrm{WR}]_{8}$ reduced cell proliferation at $25 \mu \mathrm{M}$ by 21 and $23 \%$, respectively, after $24 \mathrm{~h}$ incubation. [WR] $]_{9}$ showed significant toxicity and reduced the cell proliferation at $25 \mu \mathrm{M}$ by $55 \%$. $[\mathrm{WR}]_{7}$ and $[\mathrm{WR}]_{9}$ exhibited significantly more cytotoxicity after $72 \mathrm{~h}$ (Figure 2).

Further studies were required to find a noncytotoxic concentration for $[\mathrm{WR}]_{9}$. To evaluate the cytotoxicity of $[\mathrm{WR}]_{9}$, cell viability assay was conducted in LLC-PK1 cell line at the experimental concentration of 1,5 , and $10 \mu \mathrm{M}$. The percentage of cell survival demonstrated that $[\mathrm{WR}]_{9}$ reduced cell viability by $19-23 \%$ at $24 \mathrm{~h}$ at these concentrations, whereas Dox was cytotoxic at $5 \mu \mathrm{M}$ reducing the cell viability by $79 \%$ (Figure 3 ). These studies showed that the toxicity of $[\mathrm{WR}]_{9}$ precluded it from being used at a higher concentration and suggested that this compound could be used alternatively as an anticancer agent at higher concentrations.

To determine a noncytotoxic concentration for all of $[\mathrm{WR}]_{x}$ $(x=5-9)$, cell viability assay was conducted in LLC-PK1 cell 
Scheme 2. Synthesis of $F^{\prime}-\left[W_{9} R_{8} K\right]$
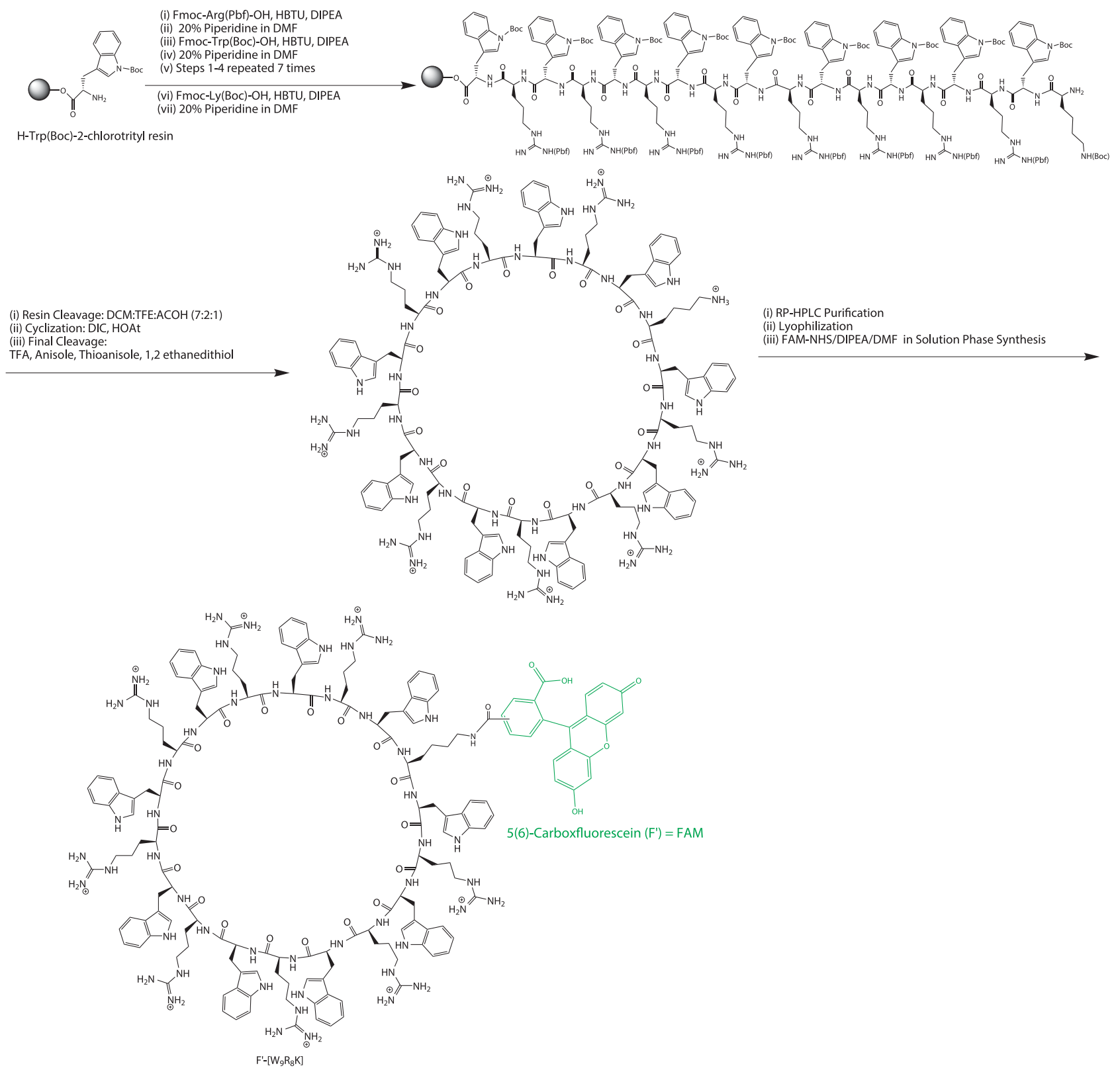

line at the experimental concentration of $10 \mu \mathrm{M}$. Dox $(5 \mu \mathrm{M})$ was used as the positive control. The percentage of cell survival demonstrated that all the peptides, including $[\mathrm{WR}]_{9}$, showed less toxicity at this concentration $(10 \mu \mathrm{M})$, whereas Dox was significantly cytotoxic even at $5 \mu \mathrm{M}$ (Figure 4). Surprisingly, the peptides were less cytotoxic after $72 \mathrm{~h}$ incubation (Figures 3 and 4).

After selecting a nontoxic concentration of peptides, a viability assay was performed at $10 \mu \mathrm{M}$ against human leukemia CCRF-CEM carcinoma cell line after $3 \mathrm{~h}$ incubation (Figure 5). [WR $]_{9}$ showed reduced cell viability by $23 \%$. The cytotoxicity of peptides was also evaluated at a concentration of $10 \mu \mathrm{M}$ against LLC-PK1 after $3 \mathrm{~h}$ (Figure 5). [WR], reduced the cell viability by $10 \%$. The data indicate that the peptide was less toxic against kidney cells at $10 \mu \mathrm{M}$ concentration after $3 \mathrm{~h}$ incubation. Thus, this concentration was used for performing cellular uptake studies.
Cellular Uptake Studies. Cellular Uptake of A Fluorescence-Labeled Phosphopeptide in the Presence of the Peptides. Flow cytometry studies were performed by fluorescence-activated cell sorter (FACS) using CCRF-CEM to measure the uptake of fluorescence-labeled phosphopeptide $\left(\mathrm{F}^{\prime}\right.$-GpYEEI, $\left.2 \mu \mathrm{M}\right)$ in the presence of $[\mathrm{WR}]_{5},[\mathrm{WR}]_{6},[\mathrm{WR}]_{7}$, $[\mathrm{WR}]_{8}$, and $[\mathrm{WR}]_{9}(10 \mu \mathrm{M})$. Cells and fluorescence-labeled phosphopeptide alone were used as negative controls. After $3 \mathrm{~h}$ incubation, CCRF-CEM cells were analyzed by flow cytometry (Figure 6). [WR $]_{9}(10 \mu \mathrm{M})$ significantly enhanced the cellular uptake of $\mathrm{F}^{\prime}$-GpYEEI $(2 \mu \mathrm{M})$ when compared with the other cyclic peptides. On the basis of the results, the physical mixture of $\mathrm{F}^{\prime}$-GPYEEI $(2 \mu \mathrm{M})$ with $[\mathrm{WR}]_{9}(10 \mu \mathrm{M})$ significantly enhanced the cellular uptake by 20 -fold when compared to $\mathrm{F}^{\prime}$ GpYEEI $(2 \mu \mathrm{M})$ alone, whereas the physical mixture of $\mathrm{F}^{\prime}$ GpYEEI $(2 \mu \mathrm{M})$ with $[\mathrm{WR}]_{5}$ enhanced the uptake by 4 -fold. On the basis of these data, $[\mathrm{WR}]_{9}$ was found to be more effective when compared with $[\mathrm{WR}]_{5}$ in improving the cellular 


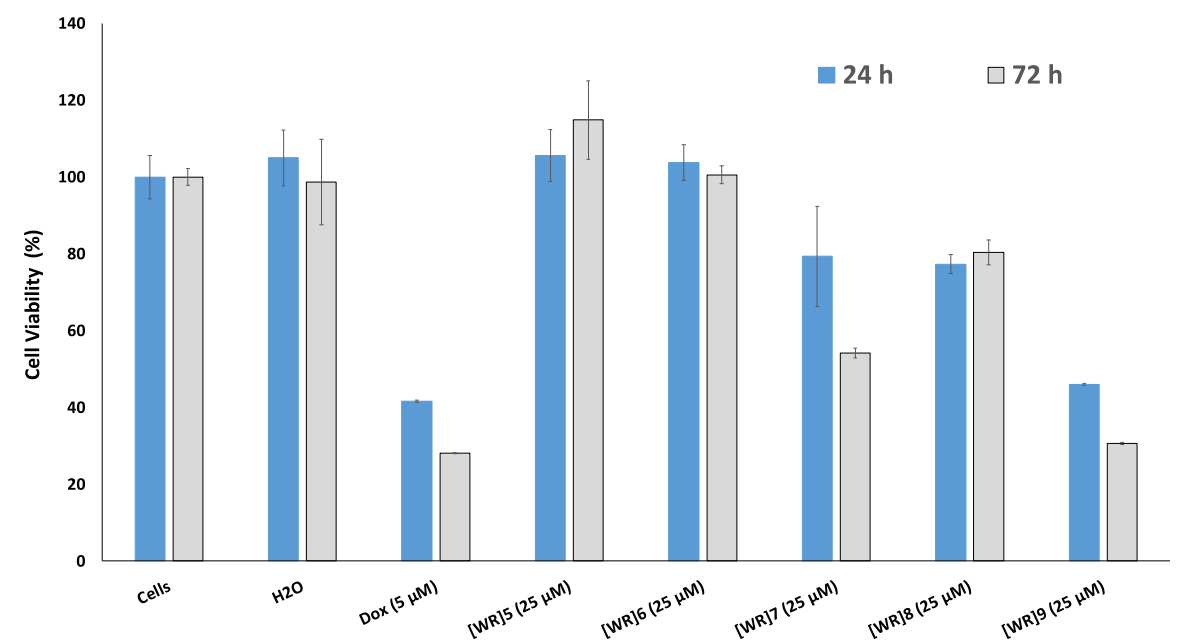

Figure 2. Cytotoxicity of cyclic peptides $(25 \mu \mathrm{M})$ in LLC-PK1 (normal kidney cells) after 24 and $72 \mathrm{~h}$ incubation using MTS assay.

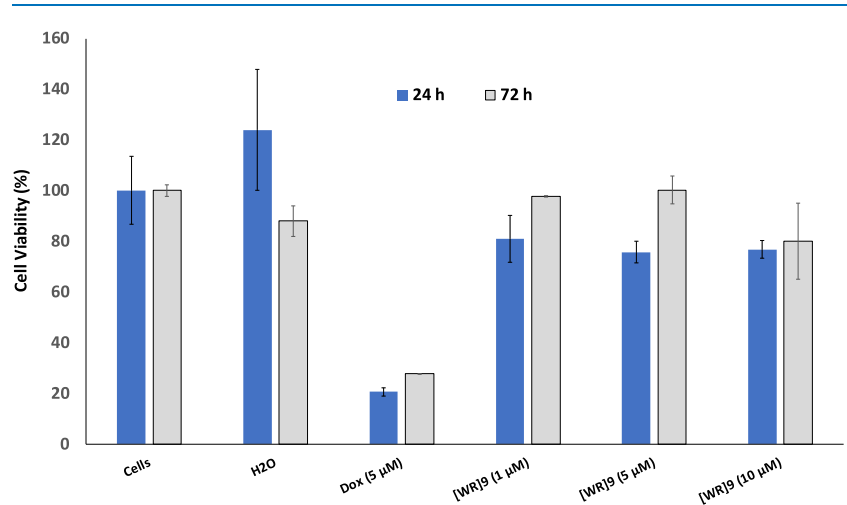

Figure 3. Cytotoxicity of $[\mathrm{WR}]_{9}(1,5$, and $10 \mu \mathrm{M})$ in LLC-PK1 (normal kidney cells) after 24 and $72 \mathrm{~h}$ incubation using MTS assay.

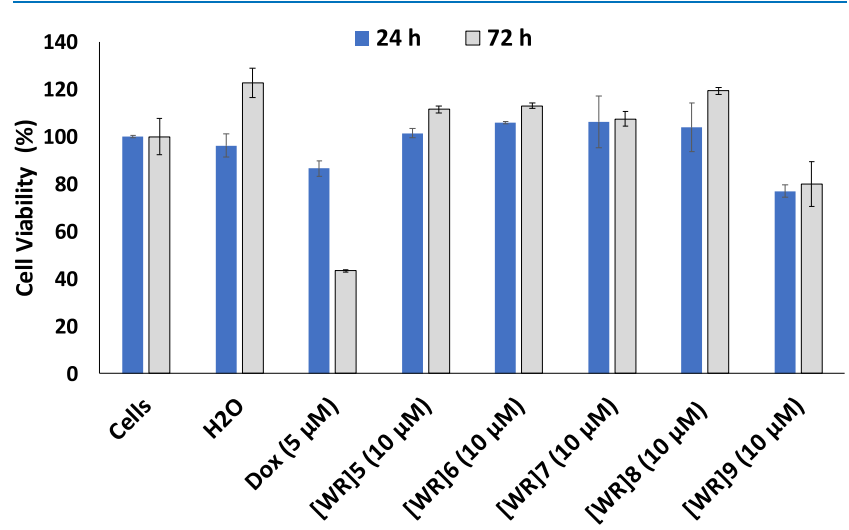

Figure 4. Cytotoxicity of cyclic peptides $(10 \mu \mathrm{M})$ in LLC-PK1 (normal kidney cells) after 24 and $72 \mathrm{~h}$ incubation using MTS assay.

uptake of the phosphopeptide, presumably because a higher number of positive charges and the larger size of $[\mathrm{WR}]_{9}$ provide adequate interaction and encapsulation of a large linear negatively charged phosphopeptide in comparison to $[\mathrm{WR}]_{5}$. Thus, cyclic $[\mathrm{WR}]_{9}$ was found to be the most effective peptide as the molecular transporter of fluorescence-labeled phosphopeptide among the synthesized peptides. Thus, further studies were performed with $[\mathrm{WR}]_{9}$.

Cellular Uptake Studies of Fluorescence-Labeled Drugs in the Presence of $[W R]_{g}$. Flow cytometry studies were performed using CCRF-CEM cells to measure the uptake of fluorescence-labeled phosphopeptide $\mathrm{F}^{\prime}$-GpYEEI $(1 \mu \mathrm{M})$ and fluorescence-labeled anti-HIV drugs, such as $\mathrm{F}^{\prime}$-d4T $(1 \mu \mathrm{M})$, $\mathrm{F}^{\prime}$-3TC $(1 \mu \mathrm{M})$, and $\mathrm{F}^{\prime}$-FTC $(1 \mu \mathrm{M})$, in the presence of $[\mathrm{WR}]_{9}(10 \mu \mathrm{M})$. The data were based on the mean fluorescence signal for 10000 cells collected (Figure 7).

The physical mixture of $\mathrm{F}^{\prime}-3 \mathrm{TC}(1 \mu \mathrm{M})$ and $\mathrm{F}^{\prime}-\mathrm{d} 4 \mathrm{~T}(1 \mu \mathrm{M})$ with $[\mathrm{WR}]_{9}(10 \mu \mathrm{M})$ significantly enhanced the cellular uptake of $\mathrm{F}^{\prime}-3 \mathrm{TC}$ and $\mathrm{F}^{\prime}$-d4T by 2 -fold, whereas the physical mixture of $\mathrm{F}^{\prime}$-FTC with $[\mathrm{WR}]_{9}$ enhanced the uptake only by 1.75 fold (Figure 7$)$. The presence of $[\mathrm{WR}]_{9}(10 \mu \mathrm{M})$ significantly enhanced the cellular uptake of the phosphopeptide, $F^{\prime}$ GpYEEI $(1 \mu \mathrm{M})$, by 4 -fold, which is less than when the phosphopeptide was used at a higher concentration $(2 \mu \mathrm{M}$, Figure 6). These data indicate that an appropriate ratio of 5 to 1 between $[\mathrm{WR}]_{9}$ and phosphopeptide is required for more efficient uptake. The presence of $[\mathrm{WR}]_{9}$ also showed enhanced cellular uptake of the anti-HIV drugs but not as significant as the phosphopeptide and in comparison to $[\mathrm{WR}]_{5} .{ }^{13}$ Thus, we assume that the cyclic structure in $[\mathrm{WR}]_{9}$ is too large, and residues in the peptide are far for adequate interaction and encapsulation, to carry small molecule drugs, such as anti-HIV drugs. However, $[\mathrm{WR}]_{9}$ showed to be significantly more efficient in the delivery of a larger linear phosphopeptide in comparison to $[\mathrm{WR}]_{5}$.

Cellular Uptake of $F^{\prime}-\left[W_{9} R_{8} K\right]$. To confirm the cellular uptake of cyclic peptide $[\mathrm{WR}]_{9}$ that contains alternating arginine and tryptophan residues, a fluorescently labeled conjugate of the peptide, $\mathrm{F}^{\prime}-\left[\mathrm{W}_{9} \mathrm{R}_{8} \mathrm{~K}\right]$, was synthesized (Scheme 2), and the cellular internalization was studied. The synthesis of the fluorescently labeled peptide was accomplished by replacing one arginine unit with a lysine residue during solid-phase peptide synthesis and attaching carboxyfluorescein $\left(\mathrm{F}^{\prime}\right)$ to the side chain of lysine in the solution phase. The cellular uptake of the selected fluorescence-labeled cyclic peptide $\mathrm{F}^{\prime}-\left[\mathrm{W}_{9} \mathrm{R}_{8} \mathrm{~K}\right]$ was observed by measuring the fluorescence in the treated cells in a concentration- and time-dependent manner and in the presence of endocytosis inhibitors.

Flow cytometry studies were performed in CCRF-CEM cells to determine the uptake of $\mathrm{F}^{\prime}-\left[\mathrm{W}_{9} \mathrm{R}_{8} \mathrm{~K}\right]$ in different concentrations. The cells were incubated with 5(6)-carboxyfluorescein (FAM) $(1,5$, and $10 \mu \mathrm{M})$ and $\mathrm{F}^{\prime}-\left[\mathrm{W}_{9} \mathrm{R}_{8} \mathrm{~K}\right](1,5$, and $10 \mu \mathrm{M}$ ) for $5 \mathrm{~min}, 30 \mathrm{~min}$, and $1 \mathrm{~h}$ and were analyzed by flow cytometry (Figure 8). While the cellular uptake of FAM 


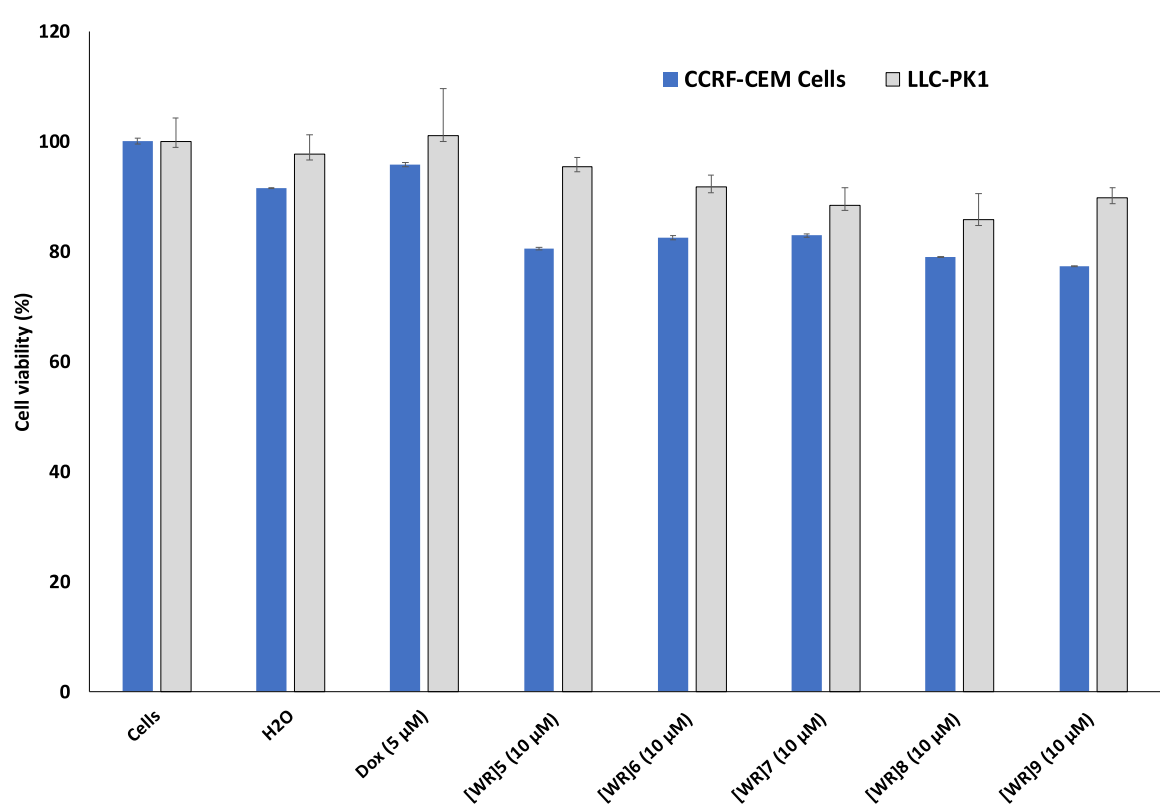

Figure 5. Cytotoxicity of cyclic peptides $(10 \mu \mathrm{M})$ in CCRF-CEM and LLC-PK1 after $3 \mathrm{~h}$ incubation using MTS assay.

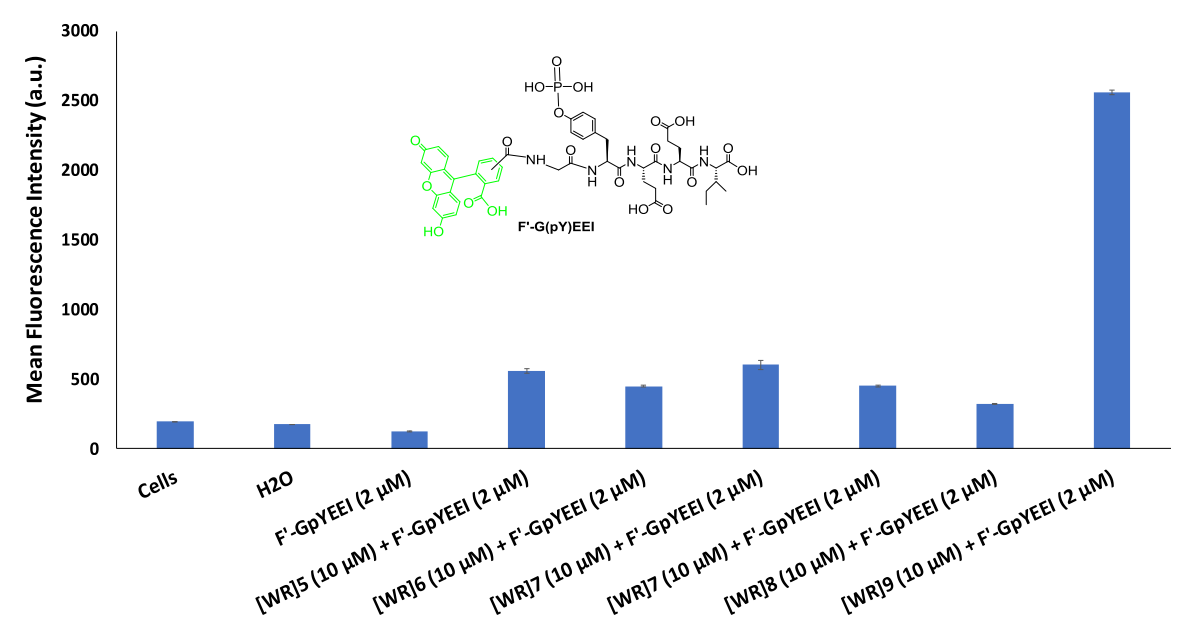

Figure 6. Intracellular uptake of $\mathrm{F}^{\prime}$-GpYEEI $(2 \mu \mathrm{M})$ by $[\mathrm{WR}]_{5},[\mathrm{WR}]_{6},[\mathrm{WR}]_{7},[\mathrm{WR}]_{8}$, and $[\mathrm{WR}]_{9}(10 \mu \mathrm{M})$ after $3 \mathrm{~h}$ incubation in CCRF-CEM cell line.

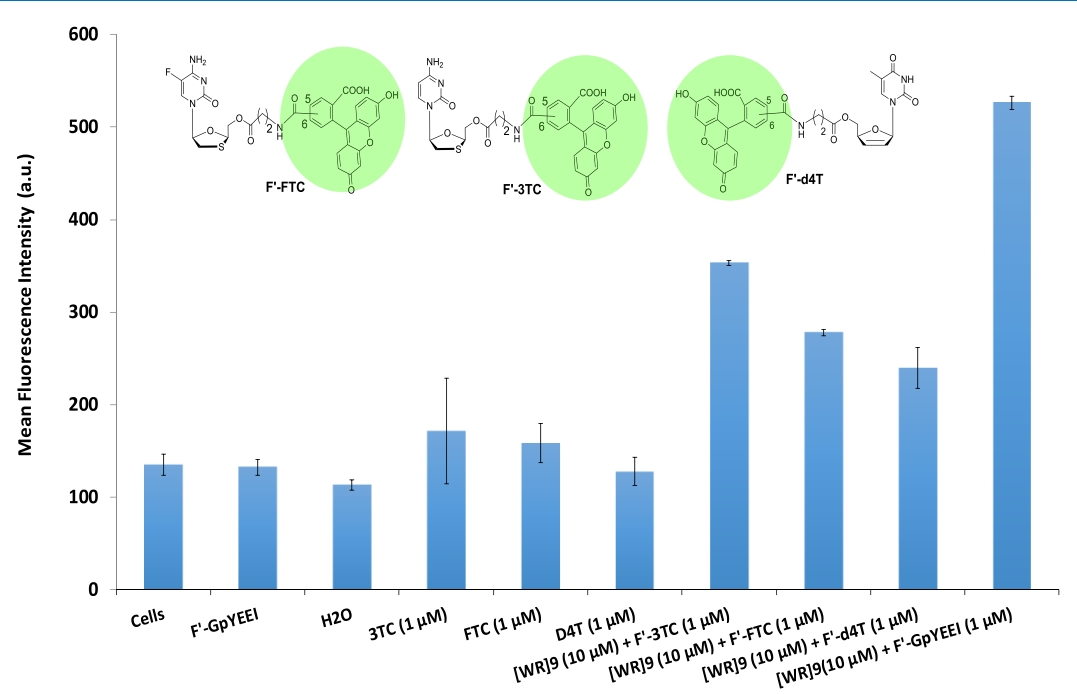

Figure 7. Intracellular uptake of anti-HIV drugs $\left[\mathrm{F}^{\prime}\right.$-FTC $(1 \mu \mathrm{M}), \mathrm{F}^{\prime}-3 \mathrm{TC}(1 \mu \mathrm{M})$, and $\mathrm{F}^{\prime}$-d4T $\left.(1 \mu \mathrm{M})\right]$ and $\mathrm{F}^{\prime}$-GpYEEI $(1 \mu \mathrm{M})$ with $[\mathrm{WR}]_{9}(10$ $\mu \mathrm{M})$ in CCRF-CEM cells after $3 \mathrm{~h}$ incubation. 


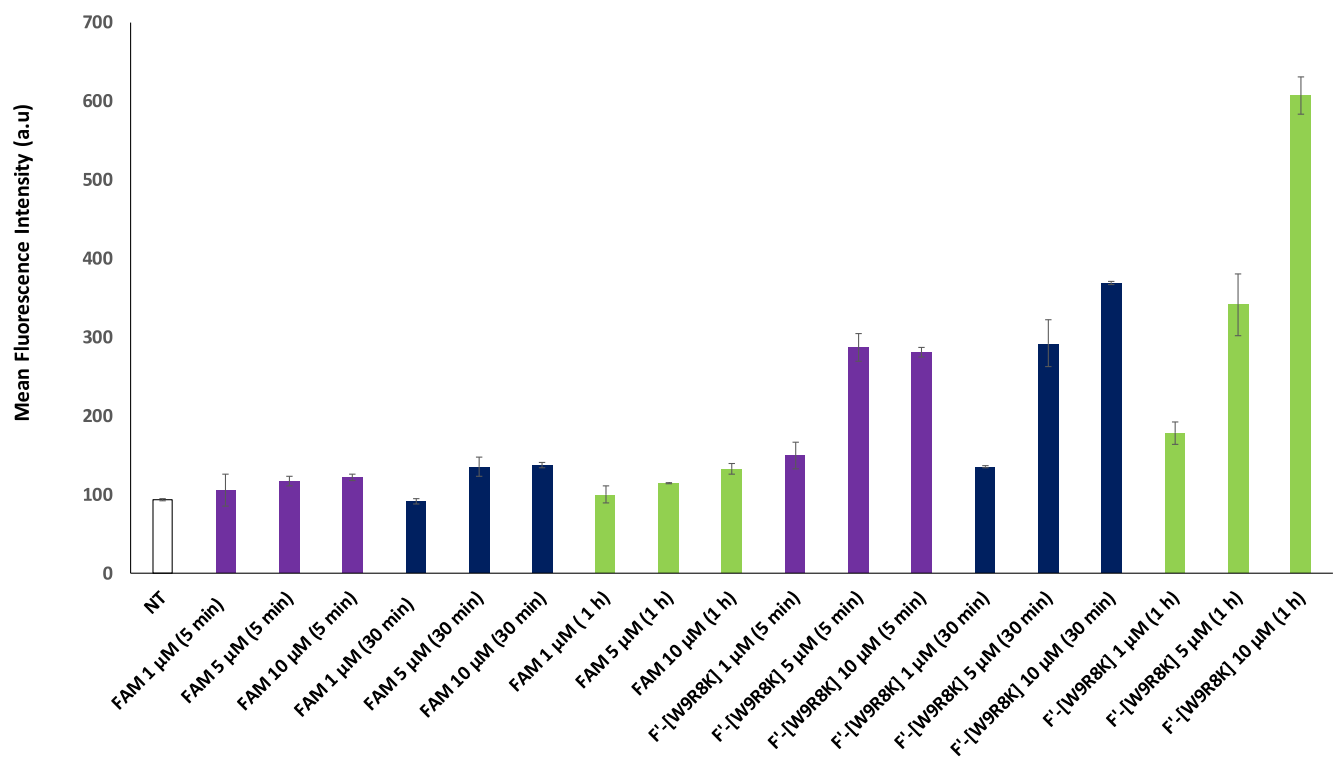

Figure 8. Dose- and time-dependent cellular uptake of $\operatorname{FAM}(1,5,10 \mu \mathrm{M})$ and $\mathrm{F}^{\prime}-\left[\mathrm{W}_{9} \mathrm{R}_{8} \mathrm{~K}\right](1,5,10 \mu \mathrm{M})$ in CCRF cells, after 5 min, 30 min, and $1 \mathrm{~h}$ incubation. NT is no treatment.

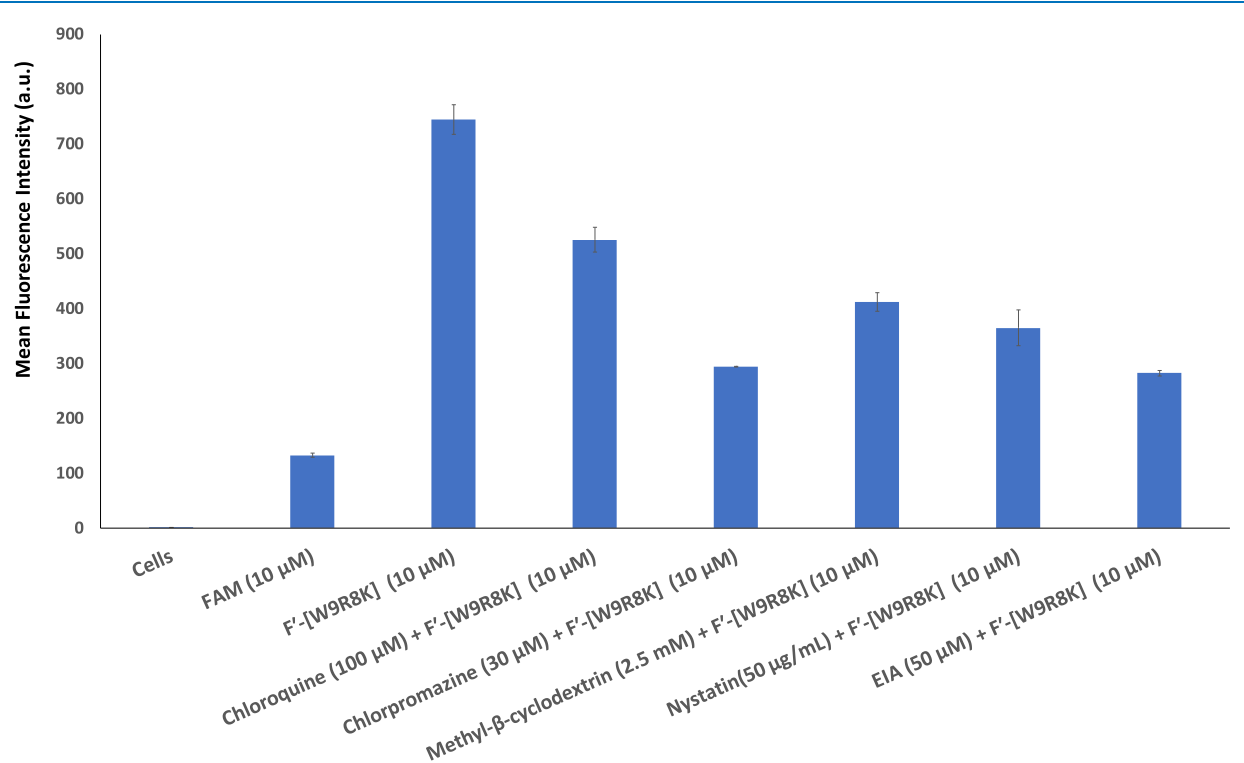

Figure 9. Cellular uptake of $\mathrm{F}^{\prime}-\left[\mathrm{W}_{9} \mathrm{R}_{8} \mathrm{~K}\right](10 \mu \mathrm{M})$ in CCRF-CEM cells pre-incubated with endocytosis inhibitors $(30 \mathrm{~min})$ after $1 \mathrm{~h}$ incubation.

did not improve as the concentration increased, the cellular uptake of $\mathrm{F}^{\prime}-\left[\mathrm{W}_{9} \mathrm{R}_{8} \mathrm{~K}\right]$ was significantly enhanced in a concentration-dependent manner with the highest uptake at $10 \mu \mathrm{M}$. The cellular uptake of the peptide was also timedependent and was at its highest after $1 \mathrm{~h}$. Thus, the cellular uptake of the fluorescently labeled peptide was found to be concentration- and time-dependent. $\mathrm{F}^{\prime}-\left[\mathrm{W}_{9} \mathrm{R}_{8} \mathrm{~K}\right]$ was not significantly cytotoxic at this concentration $(10 \mu \mathrm{M})$ and time periods.

Mechanistic Studies. To determine whether the cellular uptake was endocytosis-dependent, the transport of fluorescence-labeled peptide $\mathrm{F}^{\prime}-\left[\mathrm{W}_{9} \mathrm{R}_{8} \mathrm{~K}\right](10 \mu \mathrm{M})$ was examined in the presence of endocytosis inhibitors (Figure 9). CCRF-CEM cells were pre-incubated by various inhibitors, including nystatin chloroquine, chlorpromazine, methyl- $\beta$-cyclodextrin, and 5-(N-ethyl- $N$-isopropyl)amiloride (EIA) for $30 \mathrm{~min}$. The cells were then incubated with $\mathrm{F}^{\prime}-\left[\mathrm{W}_{9} \mathrm{R}_{8} \mathrm{~K}\right](10 \mu \mathrm{M})$ for $1 \mathrm{~h}$. The uptake of $\mathrm{F}^{\prime}-\left[\mathrm{W}_{9} \mathrm{R}_{8} \mathrm{~K}\right]$ decreased in the presence of chloroquine but was significantly reduced in the presence of methyl- $\beta$-cyclodextrin, chlorpromazine, EIA, and nystatin. This suggests that the mechanism of uptake could be dependent on clathrin-mediated or caveolae-mediated endocytosis and phagocytosis. However, the inhibitors did not block the uptake of cargo completely, suggesting that other pathways are also involved in the delivery of $\mathrm{F}^{\prime}-\left[\mathrm{W}_{9} \mathrm{R}_{8} \mathrm{~K}\right]$.

Adenosine 5'-triphosphate (ATP) depletion was used to determine whether $\mathrm{F}^{\prime}-\left[\mathrm{W}_{9} \mathrm{R}_{8} \mathrm{~K}\right](10 \mu \mathrm{M})$ uptake is energydependent. CCRF-CEM cells were pre-incubated with $0.5 \%$ of $75 \mathrm{mM}$ sodium azide in opti-minimum Eagle's essential medium (MEM) for $30 \mathrm{~min}$ prior to the addition of the compound, followed by $1 \mathrm{~h}$ incubation. Although the cellular uptake of $\mathrm{F}^{\prime}-\left[\mathrm{W}_{9} \mathrm{R}_{8} \mathrm{~K}\right](10 \mu \mathrm{M})$ was reduced by 1.8 -fold in the presence of sodium azide, significant intracellular uptake was still observed, suggesting that the uptake is not significantly reduced by inducing ATP depletion (Figure 10). Thus, different mechanisms may contribute to the peptide's cellular 


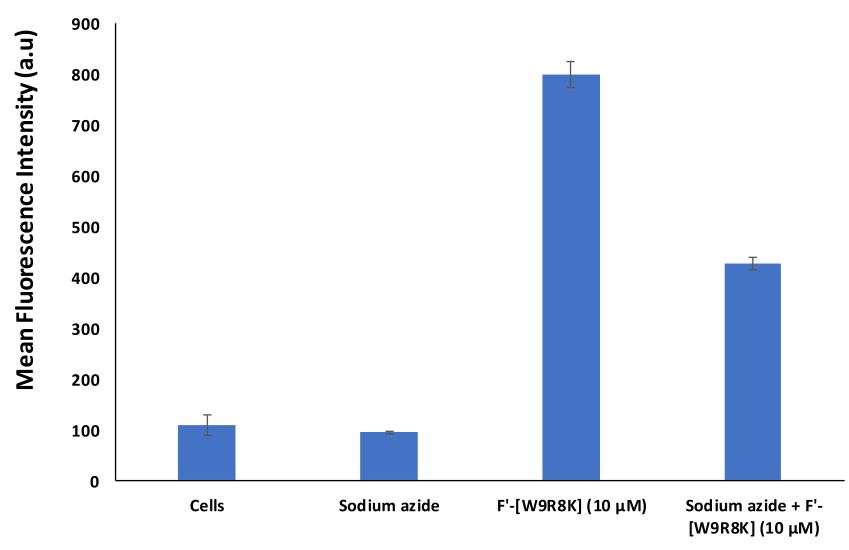

Figure 10. Cellular uptake of $\mathrm{F}^{\prime}-\left[\mathrm{W}_{9} \mathrm{R}_{8} \mathrm{~K}\right](10 \mu \mathrm{M})$ in CCRF-CEM cells pre-incubated with sodium azide $(375 \mu \mathrm{M})$ for $1 \mathrm{~h}$, followed by 1 $\mathrm{h}$ incubation.

uptake. The cellular uptake of the peptide decreased significantly by 5.6 -fold when incubated at $4{ }^{\circ} \mathrm{C}$ (Figure 11), suggesting that the uptake of $\mathrm{F}^{\prime}-\left[\mathrm{W}_{9} \mathrm{R}_{8} \mathrm{~K}\right]$ is significantly affected by temperature.

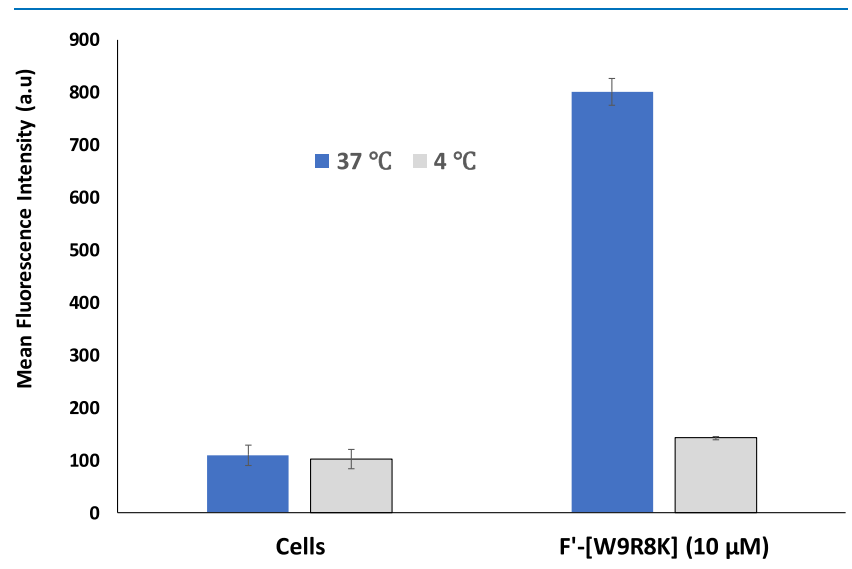

Figure 11. Cellular uptake of $\mathrm{F}^{\prime}-\left[\mathrm{W}_{9} \mathrm{R}_{8} \mathrm{~K}\right](10 \mu \mathrm{M})$ in CCRF-CEM cells pre-incubated at $4{ }^{\circ} \mathrm{C}$ for 30 min compared with CCRF-CEM cells pre-incubated at $37^{\circ} \mathrm{C}$, followed by $1 \mathrm{~h}$ incubation.

Fluorescence Microscopy. Fluorescence microscopy was performed using CCRF-CEM cells to monitor the cellular uptake of $\mathrm{F}^{\prime}-\left[\mathrm{W}_{9} \mathrm{R}_{8} \mathrm{~K}\right]$. Figure 12 shows intracellular/cellular localization (in the nucleus and cytoplasm) of $\mathrm{F}^{\prime}-\left[\mathrm{W}_{9} \mathrm{R}_{8} \mathrm{~K}\right]$ $(10 \mu \mathrm{M})$ in CCRF-CEM cells after $3 \mathrm{~h}$ incubation at $37^{\circ} \mathrm{C}$. These data indicate that the peptide has a cell permeability property and could be used in transporting appropriate cargo molecules across the cellular membrane as described above.
However, the exact localization of the peptide needs further investigation.

Fluorescence microscopy studies were conducted to demonstrate the cellular uptake of $\mathrm{F}^{\prime}$-GpYEEI $(2 \mu \mathrm{M})$ in the presence and absence of $[\mathrm{WR}]_{9}(10 \mu \mathrm{M})$ (Figure 13). $\mathrm{F}^{\prime}$ GpYEEI alone did not show any significant uptake. However, there was a significant difference in the uptake of $\mathrm{F}^{\prime}$-GpYEEI in the presence of $[\mathrm{WR}]_{9}$. These data confirm that $[\mathrm{WR}]_{9}$ can act as a molecular transporter of the negatively charged $\mathrm{F}^{\prime}$ GpYEEI.

\section{CONCLUSIONS}

A number of cyclic amphipathic peptide-containing arginine and tryptophan residues, namely $[\mathrm{WR}]_{5},[\mathrm{WR}]_{6},[\mathrm{WR}]_{7}$, $[\mathrm{WR}]_{8}$, and $[\mathrm{WR}]_{9}$ were synthesized through Fmoc solidphase chemistry and compared for their efficiency in improving the cellular uptake of cell-impermeable compounds and establish a structure-molecular transporter efficiency relationship. The synthesized peptides were found not to be significantly toxic to normal kidney cell line (LLC-PK1) at $10 \mu \mathrm{M}$ after $3 \mathrm{~h}$ incubation when compared with CCRF-CEM cell lines. Among all the synthesized peptides, $[\mathrm{WR}]_{9}(10 \mu \mathrm{M})$ significantly improved the uptake of $\mathrm{F}^{\prime}$-GPYEEI by approximately 20 -fold as compared to $[\mathrm{WR}]_{5}$ which showed 4 -fold uptake. The cellular uptake of fluorescently labeled conjugate $\mathrm{F}^{\prime}-\left[\mathrm{W}_{9} \mathrm{R}_{8} \mathrm{~K}\right]$ was found to be time- and concentrationdependent. The cellular uptake of fluorescence-labeled conjugates, $\mathrm{F}^{\prime}$-FTC, $\mathrm{F}^{\prime}$-3TC, and $\mathrm{F}^{\prime}$-d4T, was slightly increased in CCRF-CEM cells, in the presence of $[\mathrm{WR}]_{9}$ as compared to the drugs alone. However, $[\mathrm{WR}]_{9}$ showed to be the most efficient in improving the uptake of the phosphopeptide. The presence of different endocytosis inhibitors reduced the cellular uptake of $\mathrm{F}^{\prime}-\left[\mathrm{W}_{9} \mathrm{R}_{8} \mathrm{~K}\right]$ in CCRF-CEM cells. However, these inhibitors did not completely block the uptake. Therefore, we can conclude the uptake of this peptide is not completely dependent on endocytosis and other mechanisms of entry are possible. Intracellular cellular localization (in the nucleus and cytoplasm) of $\mathrm{F}^{\prime}-\left[\mathrm{W}_{9} \mathrm{R}_{8} \mathrm{~K}\right]$ after $3 \mathrm{~h}$ incubation at $37{ }^{\circ} \mathrm{C}$ was confirmed by fluorescence microscopy in CCRF-CEM. These data suggest that increasing the number of alternating positively charged arginine residues and hydrophobic tryptophan residues in a cyclic peptide was an optimal approach for generating compounds with efficient molecular transporter properties for large molecules, such as a negatively charged phosphopeptide. The work advances the scientific knowledge in the area of cyclic peptide-based delivery systems for improving the cellular uptake of cell-impermeable compounds.

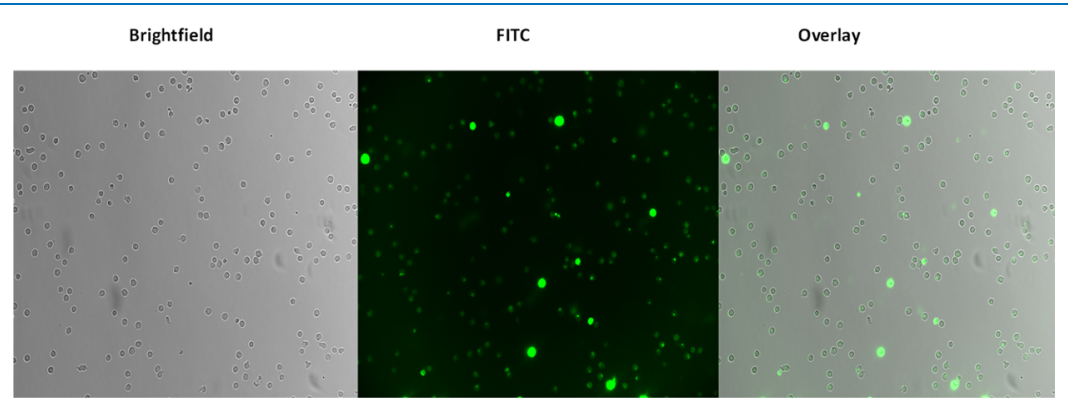

Figure 12. Fluorescence microscopy images of $\mathrm{F}^{\prime}-\left[\mathrm{W}_{9} \mathrm{R}_{8} \mathrm{~K}\right](10 \mu \mathrm{M})$ after $3 \mathrm{~h}$ incubation in the CCRF-CEM cells. 


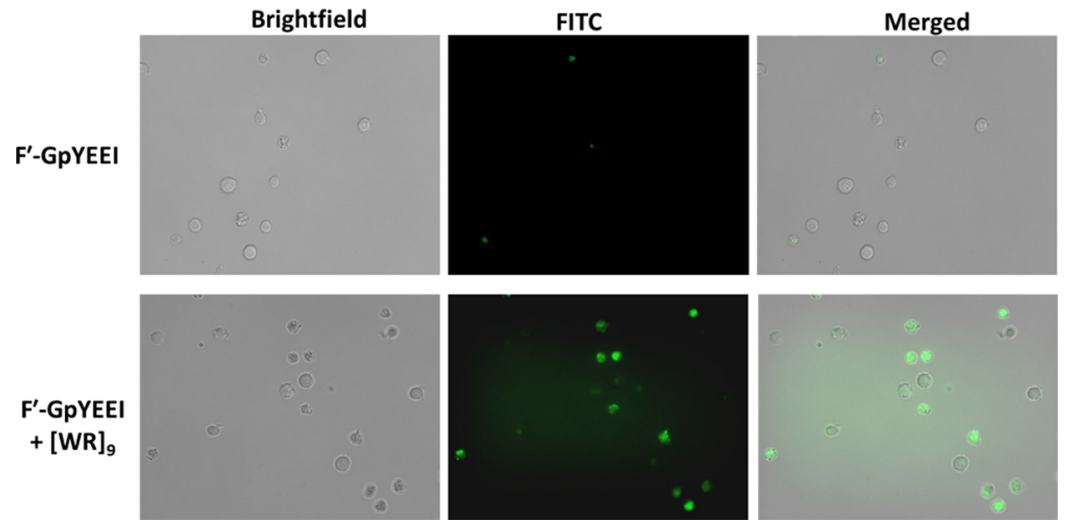

Figure 13. Cellular uptake of $\mathrm{F}^{\prime}$-GPYEEI $(2 \mu \mathrm{M})$ in the presence and absence of $[\mathrm{WR}]_{9}(10 \mu \mathrm{M})$ in CCRF-CEM after $3 \mathrm{~h}$ incubation.

\section{EXPERIMENTAL SECTION}

Materials. All amino acids and resins were obtained from AAPPTec. Other chemicals and reagents were purchased from Sigma-Aldrich. The chemical structures of the final products were confirmed by high-resolution MALDI-TOF, model \# GT 0264 from Bruker Inc. Final compounds were purified by a reversed-phase HPLC system from Shimadzu (LC-20AP) using a gradient system of acetonitrile and water and a reversed-phase preparative column (XBridge BEH130 Prep $\mathrm{C} 18)$. Fluorescence-labeled phosphopeptide ( $\mathrm{F}^{\prime}$-GpYEEI) and fluorescence-labeled anti-HIV drugs $\left[2^{\prime}, 3^{\prime}\right.$-dideoxy-5-fluoro- $3^{\prime}$ thiacytidine (FTC), 2', $3^{\prime}$-didehydro- $2^{\prime}, 3^{\prime}$-dideoxythymidine $(\mathrm{d} 4 \mathrm{~T})$, and fluorescence-labeled lamivudine (3TC)] were prepared and characterized according to the previously reported procedures. ${ }^{15,22-24}$ Human leukemia carcinoma cell line (CCRF-CEM, ATCC no. CCL-119) and normal kidney cell line (LLC-PK1, ATCC no. CRL-1392) were purchased from American Type Culture Collection (ATCC).

Methods. General Cyclic Peptide Synthesis. Fmoc-Arg(Pbf)-OH and Fmoc-Trp(Boc)-OH were used as building block amino acids in the peptide synthesis. First, the linear protected peptides $(\mathrm{W}(\mathrm{Boc}) \mathrm{R}(\mathrm{Pbf}))_{5},(\mathrm{~W}(\mathrm{Boc}) \mathrm{R}(\mathrm{Pbf}))_{6},(\mathrm{~W}$ (Boc)R(Pbf $)_{7}$, (W(Boc)R(Pbf) $)_{8}$, and (W(Boc)R(Pbf) $)_{9}$ were synthesized on $\mathrm{H}$-Trp(Boc)-2-chlorotrityl resin in 0.30 mmol scale. The $\mathrm{NH}_{2}$-Trp(Boc)-2-chlorotrityl resin was swelled in DMF under dry nitrogen for $30 \mathrm{~min}$. The solvent was filtered. The Fmoc-protected amino acid was coupled to the $N$-terminal in the presence of 2 - $(1 H$-benzotriazol-1-yl)1,1,3,3-tetramethyluronium hexafluorophosphate (3 equiv), DIPEA (6 equiv), and DMF mixing for $1 \mathrm{~h}$ under nitrogen gas. The reaction solution was filtered after the coupling reaction completed. The resin was washed with $15 \mathrm{~mL}$ of DMF for 5 min twice. Fmoc deprotection was performed using piperidine in DMF $(20 \% \mathrm{v} / \mathrm{v}, 2 \times 15 \mathrm{~min})$. The reaction solution was filtered off, and the resin was washed with DMF $(2 \times 5 \mathrm{~min})$. The followed amino acids were coupled using the same protocol to assemble the complete linear protected peptide on trityl resin. The $\mathrm{N}$-terminal Fmoc group was deprotected on the final amino acid using piperidine in DMF $(20 \% \mathrm{v} / \mathrm{v}, 2 \times 15 \mathrm{~min})$. The resin was washed with DMF $(2 \times$ $5 \mathrm{~min})$ and methanol $(15 \mathrm{~mL}, 5 \mathrm{~min})$ and dried. The partially protected peptides were cleaved from the resin support after agitating the peptidyl resin with freshly prepared cleavage cocktail, DCM/TFE/AcOH (35 mL:10 mL:5 mL), for $3 \mathrm{~h}$. The solvents were evaporated under vacuum using low pressure after mixing with hexane $(2 \times 20 \mathrm{~mL})$ and DCM
$(2 \times 15 \mathrm{~mL})$ to remove the $\mathrm{AcOH}$ by forming an azeotropic mixture. The crude material was obtained as a white solid.

MALDI analysis was used to confirm the molecular weight of the linear peptides after small cleavage of the peptide from the resin. The protected linear peptides $(0.3 \mathrm{mmol})$ were cyclized in the presence of anhydrous DMF $(100 \mathrm{~mL})$, anhydrous DCM $(25 \mathrm{~mL})$, DIC (1.21 mmol, $188 \mu \mathrm{L})$, HOAt $(0.9 \mathrm{mmol}, 122.5 \mathrm{mg})$, and DIPEA. The cyclization reaction occurred overnight under inert condition using nitrogen. MALDI analysis was used to monitor the completion of cyclization by checking the molecular weight of the cyclized peptide. The solvents were removed under low pressure. A freshly prepared cleavage cocktail, trifluoroacetic acid, anisole, thioanisole, and 1,2-ethanedithiol (6300 $\mu \mathrm{L}: 350 \mu \mathrm{L}: 210 \mu \mathrm{l}: 140$ $\mu \mathrm{L}$ ), was added to the mixture and stirred for $3 \mathrm{~h}$. The cold diethyl ether was added to precipitate the crude peptide and was centrifuged to obtain solid peptide. MALDI analysis confirmed the molecular weight of the cyclic peptides without any protecting groups. All the peptides were purified using reversed-phase HPLC and lyophilized.

A fluorescence-labeled derivative of the selected cyclic peptide $[\mathrm{WR}]_{9}$ was synthesized as $\mathrm{F}^{\prime}-\left[\mathrm{W}_{9} \mathrm{R}_{8} \mathrm{~K}\right]$, according to the solid-phase synthesis strategy described above. The $N$ terminal arginine was replaced with a lysine amino acid to facilitate labeling with carboxyfluorescein $\left(F^{\prime}\right)$. After the synthesis and purification of the peptide $\left[\mathrm{W}_{9} \mathrm{R}_{8} \mathrm{~K}\right]$, the lyophilized powder of $\left[\mathrm{W}_{9} \mathrm{R}_{8} \mathrm{~K}\right]$ peptide $(4.5 \mathrm{mg}, 1.47 \mu \mathrm{mol})$ and FAMNHS $(2.0 \mathrm{mg}, 4,2 \mu \mathrm{mol})$ was coupled using DIPEA (5.12 $\mu \mathrm{L}, 29.4 \mu \mathrm{mol})$ in anhydrous DMF $(1 \mathrm{~mL})$. The coupling reaction was completed overnight. The purification was conducted according to the described general method above used for other cyclic peptides to yield $\mathrm{F}^{\prime}-\left[\mathrm{W}_{9} \mathrm{R}_{8} \mathrm{~K}\right]$ (Scheme 2). The peptides had a purity of $>95 \%$ according to the HPLC analysis.

$[\mathrm{WR}]_{6}:$ MALDI-TOF $(\mathrm{m} / z)$ for $\mathrm{C}_{104} \mathrm{H}_{134} \mathrm{~N}_{34} \mathrm{O}_{12}$ : calcd 2051.0920; found 2051.9684 [M + H $]^{+}$; $[\mathrm{WR}]_{7}$ : MALDI-TOF $(\mathrm{m} / z)$ for $\mathrm{C}_{119} \mathrm{H}_{154} \mathrm{~N}_{42} \mathrm{O}_{14}$ : calcd 2395.2630; found 2396.6132 $[\mathrm{M}+\mathrm{H}]^{+}$; $[\mathrm{WR}]_{8}$ : MALDI-TOF $(m / z)$ for $\mathrm{C}_{136} \mathrm{H}_{176} \mathrm{~N}_{48} \mathrm{O}_{16}$ : calcd 2737.4434; found 2738.1264 $[\mathrm{M}+\mathrm{H}]^{+}$; [WR $]_{9}$ : MALDI-TOF $(m / z)$ for $\mathrm{C}_{153} \mathrm{H}_{198} \mathrm{~N}_{54} \mathrm{O}_{18}$ : calcd 3079.6238; found $3080.3276[\mathrm{M}+\mathrm{H}]^{+} ; \mathrm{F}^{\prime}-\left[\mathrm{W}_{9} \mathrm{R}_{8} \mathrm{~K}\right]$ : MALDI-TOF $(\mathrm{m} / z)$ for $\mathrm{C}_{174} \mathrm{H}_{208} \mathrm{~N}_{52} \mathrm{O}_{24}$ : calcd 3409.6654; found 3411.1455 [M+ $2 \mathrm{H}]^{+}$.

In Vitro Cytotoxicity Assay of Peptides. The in vitro cytotoxicity of the peptides was evaluated using human leukemia carcinoma cell line (CCRF-CEM, ATCC no. CCL119 ) and normal kidney cell line (LLC-PK1, ATCC no. CRL- 
1392) to determine the viability of the peptides according to the previously reported procedure. ${ }^{10}$ CCRF-CEM cells were seeded at 50000 cells in $0.1 \mathrm{~mL}$ per well in 96-well plates. LLC-PK1 cells were seeded at 5000 cells in $0.1 \mathrm{~mL}$ per well in 96-well plates. Both cell lines were seeded in medium RPMI1640 containing fetal bovine serum (10\%), $24 \mathrm{~h}$ prior to the experiment as per manufacture protocol. ${ }^{9}$ The compounds were added to each well in triplicates at a concentration of 10 $\mu \mathrm{M}$ and incubated at $37{ }^{\circ} \mathrm{C}$ for $24 \mathrm{~h}$ in a humidified atmosphere of $5 \% \mathrm{CO}_{2}$. The compounds were tested at different concentrations $(1-50 \mu \mathrm{M})$ and were added to each well in triplicate and incubated for 3,24 , and $72 \mathrm{~h}$ at $37^{\circ} \mathrm{C}$ in a humidified atmosphere of $5 \% \mathrm{CO}_{2}$. Cell viability was then determined by measuring the fluorescence intensity at $490 \mathrm{~nm}$ using a SpectraMax M2 microplate spectrophotometer. The percentage of cell survival was calculated as [(optical density (OD) value of cells treated with the test mixture of compounds $)-(\mathrm{OD}$ value of culture medium $)] /[(\mathrm{OD}$ value of control cells $)-($ OD value of culture medium $)] \times 100 \%$.

Cellular Uptake Studies. CCRF-CEM cells were used to measure the cellular uptake of the $F^{\prime}$-GpYEEI, fluorescencelabeled 3TC ( $\left.\mathrm{F}^{\prime}-3 \mathrm{TC}\right)$, fluorescence-labeled $\mathrm{d} 4 \mathrm{~T}\left(\mathrm{~F}^{\prime}-\mathrm{d} 4 \mathrm{~T}\right)$, and fluorescence-labeled FTC ( $\mathrm{F}^{\prime}$-FTC). FACS analysis was performed in order to measure the intracellular uptake of the cargo and determine whether the presence of the peptide affects the uptake of $\mathrm{F}^{\prime}$-GpYEEI, $\mathrm{F}^{\prime}-3 \mathrm{TC}, \mathrm{F}^{\prime}$-d4T, and $\mathrm{F}^{\prime}$-FTC. The fluorescence intensity was measured in the presence and absence of the synthesized peptides. The cells $\left(5 \times 10^{5}\right.$ cells per well) were taken in 6-well plates in opti-MEM or serumfree RPMI medium. $\mathrm{F}^{\prime}$-GpYEEI, $\mathrm{F}^{\prime}$-3TC, $\mathrm{F}^{\prime}$-d4T, and $\mathrm{F}^{\prime}$-FTC at $2 \mu \mathrm{M}$ were then added to the wells containing the synthesized peptides $[\mathrm{WR}]_{x}(x=5-9)$ at $10 \mu \mathrm{M}$ for $3 \mathrm{~h}$ of incubation at $37{ }^{\circ} \mathrm{C}$ cells. $\mathrm{F}^{\prime}$-GpYEEI, $\mathrm{F}^{\prime}-3 \mathrm{TC}, \mathrm{F}^{\prime}$-d4T, and $\mathrm{F}^{\prime}$ FTC alone $(2 \mu \mathrm{M})$ were used as negative controls. After $3 \mathrm{~h}$, CCRF-CEM cells were centrifuged at $800 \mathrm{rpm}$, and the cells were collected as precipitant. The cells were then washed with PBS two times. Finally, the cells were resuspended in flow cytometry buffer and analyzed by flow cytometry (FACSCalibur: Becton Dickinson) using FITC channel and CellQuest software. The data presented were based on the mean fluorescence signal for 10000 cells collected. All assays were performed in triplicates. FACS analysis was performed to measure the fluorescence intensity intracellularly and to determine whether the cyclic peptides were facilitating the cargos to cross the membrane.

A similar study was performed by FACS using CCRF-CEM cells with $\mathrm{F}^{\prime}-3 \mathrm{TC}, \mathrm{F}^{\prime}$-d4T, and $\mathrm{F}^{\prime}$-FTC at $5 \mu \mathrm{M}$ with $3 \mathrm{~h}$ incubation in the presence and absence of the synthesized peptides. The cells $\left(5 \times 10^{5}\right.$ cells per well $)$ were incubated with the synthesized peptides (at $10 \mu \mathrm{M}$ ) for $3 \mathrm{~h}$.

Mechanistic studies werecarried out in the presence of endocytosis inhibitors, such as nystatin, chlorpromazine, chloroquine, and methyl $\beta$-cyclodextrin, to determine whether the uptake was endocytosis-dependent. CCRF-CEM cells were seeded in 6-well plates $\left(5 \times 10^{5}\right.$ cells/well $)$ in opti-MEM. The cells were pre-incubated by various inhibitors including nystatin $(50 \mu \mathrm{g} / \mathrm{mL})$, chloroquine $(100 \mu \mathrm{M})$, chlorpromazine $(30 \mu \mathrm{M})$, methyl- $\beta$-cyclodextrin $(2.5 \mathrm{mM})$, and EIA $(50 \mu \mathrm{M})$ for $30 \mathrm{~min}$. The cells were then incubated with $\mathrm{F}^{\prime}-\left[\mathrm{W}_{9} \mathrm{R}_{8} \mathrm{~K}\right]$ $(10 \mu \mathrm{M})$ and a similar concentration of inhibitors for $1 \mathrm{~h}$. To induce ATP depletion, the cells were pre-incubated with $0.5 \%$ of $150 \mathrm{mM}$ sodium azide in opti-MEM prior to the addition of the compound followed by $1 \mathrm{~h}$ incubation. FACS was performed as previously described.

Fluorescence Microscopy. CCRF-CEM cells ( $30 \mu \mathrm{L}$ of 3 $\times 10^{6}$ ) were seeded with EMEM media overnight on a glassbottom culture dish. The cells were treated with $\mathrm{F}^{\prime}-\left[\mathrm{W}_{9} \mathrm{R}_{8} \mathrm{~K}\right]$ $(10 \mu \mathrm{M})$ or $[\mathrm{WR}]_{9}(10 \mu \mathrm{M})+\mathrm{F}^{\prime}$-GpYEEI $(2 \mu \mathrm{M})$ in optiMEM and incubated for $3 \mathrm{~h}$ at $37^{\circ} \mathrm{C}$. After $3 \mathrm{~h}$ incubation, cells were centrifuged at $800 \mathrm{rpm}$ for $5 \mathrm{~min}$. The cells were then washed with $400 \mu \mathrm{L}$ of PBS and centrifuged again. The media was then added to the cells. The cells were then placed on the cover slip and were detected by using a Keyence fluorescence microscope (BZ-X700. Keyence Corp. of America, Itasca, IL).

\section{ASSOCIATED CONTENT}

\section{S Supporting Information}

The Supporting Information is available free of charge on the ACS Publications website at DOI: 10.1021/acsomega.8b02589.

High-resolution MALDI-TOF mass spectrometry data of selected peptides (PDF)

\section{AUTHOR INFORMATION}

\section{Corresponding Authors}

*E-mail: tiwari@chapman.edu. Phone: (714) 516-5483. Fax: (714) 516-5481 (R.K.T.).

*E-mail: parang@chapman.edu. Phone: (714) 516-5489. Fax: (714) 516-5481 (K.P.).

\section{ORCID $\odot$}

Rakesh K. Tiwari: 0000-0003-3701-4548

Keykavous Parang: 0000-0001-8600-0893

\section{Author Contributions}

${ }^{\dagger}$ S.E.H. and S.M. contributed equally.

\section{Notes}

The authors declare no competing financial interest.

\section{ACKNOWLEDGMENTS}

The authors would like to acknowledge financial support for this research from the Chapman University School of Pharmacy.

\section{REFERENCES}

(1) Zhou, Y.; Abagyan, R. How and why phosphotyrosinecontaining peptides bind to the $\mathrm{SH} 2$ and PTB domains. Folding Des. 1998, 3, 513-522.

(2) Machida, K.; Mayer, B. J. The SH2 domain: Versatile signaling module and pharmaceutical target. Biochim. Biophys. Acta, Proteins Proteomics 2005, 1747, 1-25.

(3) Zhou, S.; Shoelson, S. E.; Chaudhuri, M.; Gish, G.; Pawson, T.; Haser, W. G.; King, F.; Roberts, T.; Ratnofsky, S.; Lechleider, R. J. $\mathrm{SH} 2$ domains recognize specific phosphopeptide sequences. Cell 1993, 72, 767-778.

(4) Chugh, A.; Eudes, F.; Shim, Y.-S. Cell-penetrating peptides: Nanocarrier for Macromolecule Delivery in Living Cells. IUBMB Life 2010, 62, 183-193.

(5) Deshayes, S.; Morris, M. C.; Divita, G.; Heitz, F. Cell-penetrating peptides: tools for intracellular delivery of therapeutics. Cell. Mol. Life Sci. 2005, 62, 1839-1849.

(6) Maiolo, J. R.; Ferrer, M.; Ottinger, E. A. Effects of cargo molecules on the cellular uptake of arginine-rich cell-penetrating peptides. Biochim. Biophys. Acta, Biomembr. 2005, 1712, 161-172. 
(7) Mukherjee, S.; Ray, S.; Thakur, R. S. Solid lipid nanoparticles: A modern formulation approach in drug delivery system. Indian $J$. Pharmaceut. Sci. 2009, 71, 349-358.

(8) Deepa, K.; Singha, S.; Panda, T. Doxorubicin nanoconjugates. J. Nanosci. Nanotechnol. 2014, 14, 892-904.

(9) Thorn, C. F.; Oshiro, C.; Marsh, S.; Hernandez-Boussard, T.; McLeod, H.; Klein, T. E.; Altman, R. B. Doxorubicin pathways. Pharmacogenet. Genomics 2011, 21, 440-446.

(10) Jones, S. W.; Christison, R.; Bundell, K.; Voyce, C. J.; Brockbank, S. M. V.; Newham, P.; Lindsay, M. A. Characterisation of cell-penetrating peptide-mediated peptide delivery. Br. J. Pharmacol. 2005, 145, 1093-1102.

(11) Madani, F.; Lindberg, S.; Langel, Ü.; Futaki, S.; Gräslund, A. Mechanisms of cellular uptake of cell-penetrating peptides. J. Biophys. 2011, 2011, 414729.

(12) Qian, Z.; LaRochelle, J. R.; Jiang, B.; Lian, W.; Hard, R. L.; Selner, N. G.; Pei, D. Early endosomal escape of a cyclic cellpenetrating peptide allows effective cytosolic Cargo Delivery. Biochemistry 2014, 53, 4034-4046.

(13) Mandal, D.; Nasrolahi Shirazi, A.; Parang, K. Cell-penetrating homochiral cyclic peptides as nuclear-targeting molecular transporters. Angew. Chem., Int. Ed. 2011, 50, 9633-9637.

(14) Shirazi, A. N.; El-Sayed, N. S.; Tiwari, R. K.; Tavakoli, K.; Parang, K. Cyclic peptide containing hydrophobic and positively charged residues as a drug delivery system for curcumin. Curr. Drug Deliv. 2016, 13, 409-417.

(15) Shirazi, A. N.; Tiwari, R. K.; Oh, D.; Banerjee, A.; Yadav, A.; Parang, K. Efficient delivery of cell-impermeable phosphopeptides by a cyclic peptide amphiphile containing tryptophan and arginine. Mol. Pharm. 2013, 10, 2008-2020.

(16) Shirazi, A.; Paquin, K.; Howlett, N.; Mandal, D.; Parang, K. Cyclic peptide-capped gold nanoparticles for enhanced siRNA delivery. Molecules 2014, 19, 13319-13331.

(17) Shirazi, A. N.; Tiwari, R.; Chhikara, B. S.; Mandal, D.; Parang, $\mathrm{K}$. Design and biological evaluation of cell-penetrating peptidedoxorubicin conjugates as prodrugs. Mol. Pharm. 2013, 10, 488-499.

(18) Sayeh, N.; Shirazi, A.; Oh, D.; Sun, J.; Rowley, D.; Banerjee, A.; Yadav, A.; Tiwari, R.; Parang, K. Amphiphilic triazolyl peptides: Synthesis and evaluation as nanostructures. Curr. Org. Chem. 2014, $18,2665-2671$.

(19) Shirazi, A. N.; Tiwari, R. K.; Oh, D.; Sullivan, B.; Kumar, A.; Beni, Y. A.; Parang, K. Cyclic peptide-selenium nanoparticles as drug transporters. Mol. Pharm. 2014, 11, 3631-3641.

(20) Ramos-Molina, B.; Lick, A. N.; Nasrolahi Shirazi, A.; Oh, D.; Tiwari, R.; El-Sayed, N. S.; Parang, K.; Lindberg, I. Cationic cellpenetrating peptides are potent furin inhibitors. PloS One 2015, 10, No. e0130417.

(21) Banerjee, A.; Sayeh, N.; Nasrolahi Shirazi, A.; Tiwari, R.; Parang, K.; Yadav, A. Arginine-rich Cyclic Peptides Enhance Cellular Delivery of Anticancer Agents: Molecular Insights. Lett. Drug Des. Discovery 2016, 13, 591-604.

(22) Agarwal, H. K.; Loethan, K.; Mandal, D.; Doncel, G. F.; Parang, $\mathrm{K}$. Synthesis and biological evaluation of fatty acyl ester derivatives of 2',3'-didehydro-2',3'-dideoxythymidine. Bioorg. Med. Chem. Lett. 2011, 21, 1917-1921.

(23) Agarwal, H. K.; Chhikara, B. S.; Hanley, M. J.; Ye, G.; Doncel, G. F.; Parang, K. Synthesis and Biological Evaluation of Fatty Acyl Ester Derivatives of (-)-2', $3^{\prime}$-Dideoxy-3'-thiacytidine. J. Med. Chem. 2012, 55, 4861-4871.

(24) Agarwal, H. K.; Chhikara, B. S.; Bhavaraju, S.; Mandal, D.; Doncel, G. F.; Parang, K. Emtricitabine prodrugs with improved antiHIV activity and cellular uptake. Mol. Pharm. 2013, 10, 467-476. 